This is an Accepted Manuscript of an article published by Taylor \& Francis in International Feminist Journal of Politics vol. 19, no. 3, pp. 381-382 on 19 May 2017, available online: http:// dx.doi.org/10.1080/14616742.2017.1324092

\title{
One Afternoon in Mytilini
}

\section{Anitta Kynsilehto, University of Tampere}

The ferryboat has been there all day long, its engine kept running. Its cargo hold is expecting entries with its throat wide open. Earlier in the day there was another ferryboat that left for the north of Greece, towards Kavalia. That boat was reserved for lone men, and as those sceptical of the hospitality of European states might suspect, it was directed to a location where it is easier to deport people outside the Greek territory. Uncertain of their destination and the underlying purpose of the boat trip to Kavalia, many of the men refused to board. They protested once on board as well, but in the end, the ferryboat departed.

The deal between the European Union and Turkey came into effect at midnight that night. ${ }^{1}$ Human rights organizations have called this deal the biggest officialised human trafficking operation ever seen, as the EU pours billions of euros to Turkey to keep refugees out of the European territory. According to the deal, in theory at least, those who had arrived in the Aegean islands before midnight would be transferred to mainland Greece. Those who came later would stay in confined spaces of detention. If they did not lodge an asylum claim, they would be returned to Turkey. No one knew how these processes would function in practice.

I sat on a roadblock looking at the open mouth of the ferryboat, trying to make sense of the sudden change of atmosphere on the island, and the feeling of uncertainty that everyone seemed to share. An Afghan woman, Amina, came over carrying two plates of warm food and water bottles, to be shared with her children and sister. I gave her space that, at first, she would not accept. "Better to eat sitting, no?" I said, and she finally accepted, offering me a fork to share the meal with her. I thanked her but declined, replying that I had already eaten, and that they needed the nourishment for the travel ahead of them.

We sat on the rocks with our backs to the busy harbour. Eyeing the sea and the Turkish coast a few kilometres away across the water, Amina showed me the waterfront. Gesturing vividly, she explained how the dinghy that brought them there had been too full and begun filling with water. "Water came up here," she said, indicating her armpits. "I can't swim. It was so scary."

Someone had found a volleyball, and with Amina's daughter Maya we joined a group throwing the ball. We played and smaller children ran after each bounce. It was a way of communicating without a common language properly shared by us all. I tried to use my few words of Dari while Maya translated with her quasi-fluent English. With Amina, we held arms, smiling. I tried to stop my tears falling, to push away my anxiety over their fate to embrace the present moment in full. I was happy they had made it to the Greek shore, and that they were about to be able to continue their journeys. At the same time I knew their journey was far from over. I had visited temporary camps in Athens, and I knew the harbour of Piraeus served as a tent camp for thousands of people. The border of the Former Yugoslav Republic of Macedonia, not to mention the other borders along the so-called Balkan route, had already become much more

\footnotetext{
${ }^{1}$ EU-Turkey statement, 18 M arch 2016, http:// www.consilium.europa.eu/en/press/pressreleases/2016/03/18-eu-turkey-statement/ (last accessed 23 February 2017)
} 
difficult to cross several months earlier. They might need to wait for a very long time, not knowing for how long and what exactly they could expect.

"Do you have nail polish remover?" I understood this question from Amina's gestures. I showed her my nails. They were cut short and have rarely worn nail polish. I suddenly wished I looked more feminine.

This small item I knew I could get for them before they left. I ran to the beachfront shops, looking feverishly for clippers and any other beauty items I could find. Nail polish I couldn't get but remover there was. With a small bag I ran back to the harbour, looking for the group of women. I couldn't see any of them. I became anxious. Then I raised my eyes to the ferryboat and there they were, waving and blowing kisses in my direction. What a relief! Looking at the queue slowly proceeding to the ferryboat, I noticed one of the women who had spoken with my friends. I tried to explain her that I had something for Amina, who no longer stood on the deck. She could not understand, and she would not take the bag of beauty items with her. I backed off, retreated to the bench on the beachfront. From there, I waved goodbye to the ferryboat, wishing the best of luck to everyone and hoping to hear good news very soon.

I stayed sitting on the bench until the ferryboat was no longer visible in the horizon. I was not alone. There were several young men eyeing the horizon too, with dinner bags in their hands, freshly received from the associations distributing food in the harbour. These men might find it much more difficult to get on a ferryboat to continue their journeys, despite having arrived long before that fateful midnight that signalled the rupture of the EU-Turkey agreement. We all knew something had just fundamentally changed on this island.

Anitta Kynsilehto

Tampere Peace Research Institute

Faculty of Social Sciences

FI-33014 University of Tampere

Finland

Email: anitta.kynsilehto@uta.fi

\section{Note on contributor}

Anitta Kynsilehto's research focuses on human mobility and solidarity practices in Europe and around the Mediterranean. Her work has appeared in Peace Review, International Studies Perspectives, Body \& Society and Environment and Planning A. 